\title{
PENGARUH VARIETAS KACANG TANAH (Aracis hypogaea L.) DAN DOSIS PENGAPURAN TERHADAP PENYAKIT BUSUK BATANG Sclerotium rolfsii Sacc. PADA LAHAN GAMBUT
}

The Effect of Peanut Varieties (Aracis hypogaea L.) and Dosages of Lime to Rot Stem Disease (Sclerotium rolfsii Sacc.) on Peat Land

\author{
Chairudin $^{1}$, Lola Adres Yanti ${ }^{1 *}$, Paulina Zalukhu ${ }^{2}$ \\ ${ }^{1)}$ Staf Pengajar pada Program Studi Agroteknologi, Fakultas Pertanian, Universitas Teuku \\ Umar, ${ }^{2)}$ Mahasiswa Alumni Program Studi Agroteknologi, Fakultas Pertanian, Universitas \\ Teuku Umar.
}

* Corresponding author, e-mail: lolaadresyanti@utu.ac.id; hp : +62-853-12834958.

\begin{abstract}
Peanut has high economic value because has high nutritions especially protein and fat, but the development of broad harvesting and peanut production for the last five years (2008-2012) continues to decrease. The main problem of the peanut low production are disease attacks $S$. rolfsii and the low broad harvesting. The drop of peanut production in Nusa Tenggara Barat causing harm caused by fungi S.rolfsii can reach 58,3 \% per year. Peat is potential land to be developed to farming land. Peat has high acidity so fungi S. rolfsii would be easy to develop and resulted disease severity of peanut disease. Solution of this problem is the gift of lime. This study aims (1) to test the effect of dosages of lime to peanut resistance which was infected by rot stem S. rolfsii on peat land; (2) to study interaction of peanut varieties and dosage of lime to rot stem disease attacks $S$. rolfsii on peat land. This study used factorial block randomized design $2 \times 3$ with 3 replications. The studied factors were peanut varieties and the dosage of lime. The result showed that on the effect of varieties, the widest disease percentage was on Takar 2 variety on age 21,28, 42, and 49 day after planting (DAP) that significant difference with Bison variety. The worth disease intensity was on Takar 2 variety that significant difference with Bison variety (on age 45 and 60 DAP).
\end{abstract}

Key words: dosage of lime, peanut varieties, peat land, the sclerotia of Sclerotium rolfsii

\section{PENDAHULUAN}

Kacang tanah (Arachis hypogaea L.) merupakan salah satu tanaman legum yang sudah dikenal dan dibudidayakan di Indonesia. Kacang tanah mempunyai nilai ekonomi tinggi karena kandungan gizinya terutama protein dan lemak yang tinggi, namun perkembangan luas panen dan produksi kacang tanah selama kurun waktu 5 tahun terakhir (2008-2012) terus mengalami penurunan. Beberapa kendala yang mengakibatkan rendahnya produksi kacang tanah antara lain pengolahan tanah dan pemeliharaan tanaman yang kurang optimal, serangan hama dan penyakit, penanaman varietas yang berproduksi rendah dan mutu benih yang rendah. Luas rata-rata panen kacang tanah dari tahun 2008-2012 mengalami penurunan sebesar $2.28 \%$ per tahun dan rata-rata produksi turun sebesar $1.02 \%$ per tahun. Di lain pihak kebutuhan kacang tanah terus meningkat yaitu rata-rata sebesar 900.000 ton/tahun, produksi rata-rata sebesar 771.022 ton/tahun $(85.67 \%)$ dengan volume impor rata-rata 163,745 ton/tahun 
(Direktorat budidaya aneka kacang dan umbi 2008 - 2012). Selain kendala di atas, luas lahan pertanaman kacang tanah di Indonesia rendah (Adisarwanto 2000)

Menurut Suprapto (2004), salah satu kendala teknis yang mengakibatkan rendahnya produksi kacang tanah adalah penyakit Sclerotium rolfsii. S.rolfsii merupakan salah satu fungi penyebab penyakit rebah kecambah dan busuk batang kacang tanah. Fungi ini merupakan salah satu fungi tular tanah yang dapat bertahan lama dalam bentuk sclerotia di dalam tanah, pupuk kandang dan sisa-sisa tanaman sakit. Penyakit ini ditemukan hampir disetiap pertanaman kacang tanah di seluruh dunia, sehingga mengakibatkan turunnya produksi tanaman yang akan dipanen (Timper et al. 2001). Tanaman kacang tanah yang telah terserang $S$. rolfsii pada pangkal batang akan terlihat bercak berwarna putih, dan lama kelamaan fungi ini akan menyebar di bagian pangkal batang sehingga tanaman menjadi layu dan mati (Fichtner 2010).

Hasil identifikasi penyakit pada tanaman yang terserang layu umumnya menunjukkan penyakit yang disebabkan oleh fungi $S$. rolfsii. Sebaran penyakit tular tanah ini di Indonesia sangat luas, meliputi Jawa, Sumatera, Kalimantan, Bali, Nusa Tenggara Barat, dan Nusa Tenggara Timur. Hasil survei di Sumatera Selatan menunjukkan tanaman kacang tanah di beberapa daerah tersebut terinfeksi oleh fungi $S$. rolfsii, sehingga hal ini mengakibatkan penurunan produksi (Timper et al. 2001).

Data penurunan produksi kacang tanah di Indonesia menyebabkan kerugian yang disebabkan oleh fungi $S$. rolfsii mencapai 58.3\% (Departemen Pertanian 1990). Hasil survey di lapangan, tingkat serangan $S$. rolfsii pada pertanaman kacang tanah di Mataram, Saying-sayang dan Pemenang, Kabupatan Lombok Barat, berkisar 80-90\% (Semangun 2004).

Lahan gambut merupakan lahan potensial untuk dikembangkan sebagai lahan pertanian. Luas lahan gambut
Indonesia mencapai 14.91 juta hektar atau $50 \%$ dari gambut tropika. Penyebaran utamanya pada tiga pulau besar, yaitu Kalimantan seluas 4,778,004 hektar, Sumatera seluas 6,436,649 hektar, dan Papua seluas 3,690,921 hektar (Ritung et al. 2012). Pengembangan kegiatan pertanian di lahan gambut menghadapi kendala antara lain, tingginya asam organik dan pengaruh dari patogen tular tanah, yang dapat menjadi sumber penyakit pada tanaman.

Solusi permasalahan ini adalah pemberian kapur pada tanah yang tingkat keasamannya terlalu tinggi. Pemberian kapur tidak hanya menambah kandungan $\mathrm{Ca}^{+}$, tetapi juga mengakibatkan unsur lain menjadi tersedia, baik pada lapisan ginofor maupun daerah akar tanaman, sehingga pengisian polong menjadi lebih sempurna dan hasil menjadi lebih tinggi (Sustarto et al. 1995; Lingga dan Marsono 2001). Pada penelitian ini, pemberian kapur diharapkan dapat meningkatkan ketahanan tanaman kacang tanah terhadap serangan patogen fungi $S$. rolfsii.

Penanaman kacang tanah dengan varietas unggul merupakan salah satu upaya pencegahan serangan fungi $S$. Rolfsii secara teknis. Pengunaan varietas unggul berperan dalam peningkatan produktivitas tanaman. Varietas unggul memiliki sifat diantaranya, tahan terhadap penyakit, mempunyai hasil yang lebih tinggi dan adaptif pada berbagai lingkungan (Marzuki 2007). Varietas ini di gunakan dalam penelitian ini adalah Bison dan Takar 2.

Berdasarkan uraian di atas maka penting dilakukan kajian tentang pengaruh varietas kacang tanah dan dosis pengapuran terhadap serangan penyakit busuk batang $S$. rolfsii pada lahan gambut. Penelitian ini bertujuan untuk 1) menguji pengaruh dosis pengapuran terhadap ketahanan varietas kacang tanah yang terserang penyakit busuk batang $S$. rolfsii pada lahan gambut; 2) mempelajari interaksi antara varietas kacang tanah dan dosis pengapuran terhadap serangan 
penyakit busuk batang $S$. rolfsii pada lahan gambut.

\section{BAHAN DAN METODE PENELITIAN}

\section{Waktu dan Tempat}

Penelitian ini dilakukan mulai bulan Maret sampai dengan Juni 2017. Tempat penelitian adalah Lahan gambut di Suak Puntong Kecamatan Kuala Pesisir Kabupatan Nagan Raya.

\section{Bahan dan Alat}

Bahan yang digunakan dalam penelitian ini adalah sclerotia fungi $S$. rolfsii, media PDA, media sekam, serasah, pupuk dasar (urea, $\mathrm{KCl}$ dan SP-36), kantong plastik, kapas, benih kacang tanah varietas Bison dan Takar 2, kapur dolomit, dan bahan lainnya. Alat yang digunakan yaitu Laminar Air Flow, autoclaf, corebore, termohygrometer, cangkul, parang, meteran, pisau, $\mathrm{pH}$ meter dan alat lainnya.

\section{Pelaksanaan Penelitian}

Rancangan percobaan yang digunakan dalam penelitian ini yaitu Rancangan Acak Kelompok (RAK) Faktorial 2 x 3 dengan 3 ulangan. Faktor yang diteliti adalah varietas kacang tanah dan dosis pengapuran.

Faktor varietas kacang tanah (V) terdiri dari 2 taraf yaitu :

$$
\begin{aligned}
& \mathrm{V} 1=\text { Bison } \\
& \mathrm{V} 2=\text { Takar } 2
\end{aligned}
$$

Faktor dosis pengapuran (K) terdiri dari 3 taraf yaitu :

$$
\begin{aligned}
& \mathrm{K} 0=\text { tanpa pengapuran } \\
& \mathrm{K} 1=\text { pengapuran sesuai dosis } \\
& \text { anjuran } 10 \text { ton/ha }(44.1 \mathrm{~kg} / \mathrm{plot}) \\
& \mathrm{K} 2=\text { pengapuran } 2 \mathrm{kali} \text { dosis } \\
& \text { anjuran } 20 \text { ton/ha }(88.2 \mathrm{~kg} / \mathrm{plot})
\end{aligned}
$$

\section{Perbanyakan Inokulum Patogen}

$S$. rolfsii diambil dari tanah pertanaman kacang tanah yang terinfestasi fungi ini dengan menggunakan teknik pancingan, yaitu dengan menutup selama satu minggu tanah yang terinfestasi dengan serasah sehingga kelembaban terjaga. Kemudian miselium fungi $S$. rolfsii ditanam pada media Potato Dextrosa Agar (PDA) dengan suhu inkubasinya sebesar $27^{\circ} \mathrm{C}$ hingga diperoleh biakan murni S.rolfsii. Selanjutnya biakan murni diperbanyak pada media substrat sekam. Sekam sebanyak $50 \mathrm{~g}$ dimasukkan ke dalam kantong plastik tahan panas, pada ujungnya, dipasang cincin paralon yang diikat dengan benang dan disumbat dengan kapas, kemudian disterilkan dengan menggunakan autoklaf pada suhu $121^{\circ} \mathrm{C}$ selama 15 menit. Setelah media sekam dingin, diinokulasikan $S$. rolfsii dengan diameter $0,6 \mathrm{~cm}$ sebanyak 3 potong setiap kantong dan diinkubasi selama 10 hari pada suhu kamar. Setelah sklerotia terbentuk, maka sklerotia siap diinolukasikan pada tanaman percobaan sebanyak 3 butir pada setiap tanaman sampel.

\section{Persiapan Lahan}

Pengolahan lahan dilakukan dengan menggunakan cangkul. Kemudian diukur plot dengan ukuran 275 x $125 \mathrm{~cm}$. Tiaptiap plot dibatasi oleh parit berukuran lebar $30 \mathrm{~cm}$. Jumlah plot keseluruhan yaitu sebanyak 18 plot percobaan.

\section{Pengapuran}

Setelah lahan diolah, diberi kapur dolomit sesuai perlakuan yang dicobakan. Kapur dolomit diberikan pada kedalaman $30 \mathrm{~cm}$ dari permukaan tanah dengan cara ditabur kemudian dibolak-balik bersamaan dengan pengolahan tanah (Novizan 2005). Setelah pemberian kapur dolomit, tanah didiamkan selama 14 hari. Prosedur ini juga dilakukan pada perlakuan kontrol, namun tanpa aplikasi kapur.

\section{Penanaman}

Penanaman dilakukan pada hari ke 14 setelah pengolahan tanah. Penanaman dilakukan dengan cara ditugal sedalam 3 $\mathrm{cm}$ dengan jarak tanam $25 \times 25 \mathrm{~cm}$. Tiap lubang tanam berisi 2 benih kacang tanah. 
Masing-masing plot berjumlah 55 tanaman dengan jumlah tanaman sampel sebanyak 8 tanaman/plot.

\section{Pemupukan}

Pupuk dasar diaplikasikan pada 3 hari setelah tanam, dengan cara pelarikan di antara lubang tanaman. Jenis dan dosis pupuk dasar yang diberikan adalah urea sebanyak 17.19 g/plot, SP-36 sebanyak $21.5 \mathrm{~g} / \mathrm{plot}, \mathrm{KCL}$ sebanyak $21.5 \mathrm{~g} / \mathrm{plot}$. Masing-masing dosis dalam 1 ha. Sedangkan pupuk susulan diberikan pada hari ke - 30 setelah tanam dengan dosis SP-36 sebanyak $21.5 \mathrm{~g} / \mathrm{plot}$ dan KCL sebanyak $21.5 \mathrm{~g} / \mathrm{plot}$.

\section{Inokulasi Patogen}

Fungi $S$. rolfsii diinokulasikan ke tanaman sampel pada satu minggu setelah tanam. S. rolfsii diinokulasikan ke tanaman dalam bentuk sclerotia. Sclerotia diberikan pada pangkal batang tanaman sampel sebanyak 4 setiap lubang tanam, masingmasing diberikan pada setiap perlakuan.

\section{Pemeliharaan Tanaman}

Penyiraman dilakukan pada pagi dan sore hari tergantung cuaca. Pengendalian gulma dilakukan dengan penyiangan. Pengendalian hama dilakukan apabila terjadi serangan hama. Penyulaman dilakukan ketika tanaman tidak tumbuh. Pembubunan dilakukan saat terbentuknya ginofor.

\section{Parameter Pengamatan}

Persentase Serangan (\%)

Persentase serangan dihitung pada 7 hari setelah inokulum (HSI), 14 HSI, 21 HSI, 28 HSI, 35 HSI, 42 HSI, 49 HSI. Persentase serangan $S$. rolfsii pada tanaman kacang tanah dihitung per kombinasi perlakuan menggunakan rumus (Achmad et al. 2012) sebagai berikut:

Keterangan:

$$
\mathrm{P}=\frac{a}{b} \times 100 \%
$$

$\mathrm{P}=$ Persentase serangan $(\%)$

$\mathrm{a}=$ Jumlah tanaman terserang, dan

$\mathrm{b}=$ Jumlah tanaman keseluruhan

\section{Intensitas Serangan (\%)}

Intensitas serangan dihitung pada 15, 30, 45, dan 60 HST. Intensitas serangan penyakit busuk batang dihitung dengan rumus menurut (Nurbalis 1992), sebagai berikut:

Keterangan :

$$
\text { IS }=\frac{\left(\sum \text { nivi }\right)}{\mathrm{Z} \mathrm{N}} x 100 \%
$$

IS = intensitas serangan

$\mathrm{ni}=$ jumlah tanaman yang terserang pada skor ke-i

$\mathrm{vi}=$ nilai skor ke-i

$\mathrm{N} \quad$ =jumlah seluruh yang diamati (perkombinasi perlakuan)

$\mathrm{Z}=$ skor tertinggi

Nilai skor serangan penyakit busuk batang dapat dilihat pada Tabel 2 .

Tabel 2. Nilai skor serangan penyakit busuk batang

\begin{tabular}{cl}
\hline Skor & \multicolumn{1}{c}{ Tingkat Kerusakan (\%) } \\
\hline 0 & Tidak ada kerusakan \\
1 & Serangan ringan, bercak pada pangkal, tidak layu \\
2 & Serangan berat, bercak dan layu, dan sebagian tanaman masih tumbuh \\
3 & Serangan sangat berat, layu keseluruhan dan tanaman mati \\
\hline
\end{tabular}

\section{Jumlah Sklerotia Terbentuk}

Jumlah sklerotia yang terbentuk dihitung pada tiap tanaman sampel pada umur 14 hari setelah tanam.

\section{Masa Inkubasi}

Masa inkubasi diamati sejak inokulasi patogen $(S$. rolfsii) hingga awal muncul gejala penyakit.

\section{Suhu Udara}

Suhu udara diukur setiap hari pada pagi (pukul 08.00), siang (pukul 13.00), 
dan sore (17.00) dengan menggunakan alat ukur Thermometer Household Wall selama 3 bulan (Mei, Juni dan Juli).

\section{pH Tanah}

Pengukuran $\mathrm{pH}$ tanah penelitian ini dilakukan pada pengolahan tanah dan 14 hari setelah pengapuran.

\section{HASIL DAN PEMBAHASAN}

\section{Pengaruh Varietas}

Hasil uji $F$ pada analisis ragam (Lampiran bernomor genap 3 sampai 26) menunjukkan varietas berpengaruh sangat nyata terhadap persentase tanaman terserang umur $28 \quad 42$ dan 49 HSI, intensitas serangan umur 45 dan 60 HSI. Berpengaruh nyata terhadap persentase tanaman terserang umur 21 HSI. Namun berpengaruh tidak nyata terhadap persentase tanaman terserang umur 7,14 dan 35 HSI, intensitas serangan umur 15 dan 30 HST dan jumlah sclerotia terbentuk.

\section{Persentase Tanaman Terserang (\%) \\ Rata-rata persentase tanaman} terserang penyakit busuk batang pada berbagai varietas umur $7,14,21,28,35,42$ dan 49 HSI di lahan gambut setelah diuji dengan $\mathrm{BNT}_{0.05}$ disajikan pada Tabel 3.

Tabel 3. Rata-rata persentase tanaman terserang penyakit busuk batang pada berbagai varietas umur 7, 14, 21, 28, 35, 42 dan 49 HSI di lahan gambut

\begin{tabular}{|c|c|c|c|}
\hline \multirow{2}{*}{$\begin{array}{c}\text { Umur Tanaman } \\
\text { (HSI) }\end{array}$} & \multicolumn{2}{|c|}{ Persentase Tanaman Terserang (\%) } & \multirow{2}{*}{$\mathrm{BNT}_{0.05}$} \\
\hline & Bison $\left(\mathrm{V}_{1}\right)$ & Takar2 $\left(\mathrm{V}_{2}\right)$ & \\
\hline 7 & 49.20 & 52.71 & - \\
\hline 14 & 46.67 & 53.62 & - \\
\hline 21 & $5.85 \mathrm{a}$ & $29.67 b$ & 19.26 \\
\hline 28 & $5.85 \mathrm{a}$ & $30.82 \mathrm{~b}$ & 17.09 \\
\hline 35 & 8.55 & 26.51 & - \\
\hline 42 & $4.99 \mathrm{a}$ & $35.93 \mathrm{~b}$ & 17.05 \\
\hline 49 & $4.99 \mathrm{a}$ & $37.65 \mathrm{~b}$ & 16.98 \\
\hline
\end{tabular}

Ket: Angka yang diikuti oleh huruf yang sama pada kolom yang sama tidak berbeda nyata pada taraf $5 \%\left(\mathrm{BNT}_{0.05}\right.$

Tabel 3 menunjukkan bahwa persentase tanaman terserang penyakit busuk batang tanaman kacang tanah umur 7, 14 dan 35 HSI tidak berbeda nyata pada kedua varietas yang diuji. Umur 21, 28, 42 dan 49 HSI persentase serangan yang terbesar dijumpai pada varietas Takar 2 $\left(\mathrm{V}_{2}\right)$, yang berbeda nyata dengan varietas Bison $\left(\mathrm{V}_{1}\right)$. Pada umur 35 HSI persentase serangan yang terbesar dijumpai pada varietas Takar $2\left(\mathrm{~V}_{2}\right)$, namun tidak berbeda nyata dengan varietas Bison $\left(\mathrm{V}_{1}\right)$.

Besarnya persentase serangan pada varietas Takar $2 \quad\left(\mathrm{~V}_{2}\right)$ menunjukkan varietas Takar 2 lebih rentan terhadap serangan penyakit busuk batang dibandingkan dengan varietas $\operatorname{Bison}\left(\mathrm{V}_{1}\right)$. Hal ini disebabkan oleh gen pengendali ketahanan yang dimiliki oleh kedua varietas yang berbeda sehingga ekspresi gen yang ditimbulkan terkait dengan mekanisme ketahanan juga berbeda satu sama lainnya. Menurut Singh (2006), keberhasilan mengidentifikasi adanya ketahanan penyakit tular tanah tergantung kepada keragaman genetik.

\section{Intensitas Serangan}

Rata-rata intensitas serangan penyakit busuk batang pada berbagai varietas umur 15, 30, 45 dan 60 HST di lahan gambut setelah diuji dengan $\mathrm{BNT}_{0,05}$ disajikan pada Tabel 4. 
Tabel 4. Rata-rata intensitas serangan penyakit busuk batang pada berbagai varietas umur 15 , 30, 45 dan 60 HST di lahan gambut

\begin{tabular}{cccc}
\hline \multirow{2}{*}{$\begin{array}{c}\text { Umur Tanaman } \\
(\mathrm{HST})\end{array}$} & \multicolumn{2}{c}{ Intensitas Serangan $(\%)$} & \multirow{2}{*}{$\mathrm{BNT}_{0.05}$} \\
\cline { 2 - 3 } & Bison $\left(\mathrm{V}_{1}\right)$ & Takar $2\left(\mathrm{~V}_{2}\right)$ & \\
\hline 15 & 28.81 & 34.16 & - \\
30 & 10.41 & 27.37 & - \\
45 & $6.77 \mathrm{a}$ & $28.81 \mathrm{~b}$ & 13.98 \\
60 & $8.00 \mathrm{a}$ & $31.24 \mathrm{~b}$ & 16.52 \\
\hline
\end{tabular}

Ket: Angka yang diikuti oleh huruf yang sama pada kolom yang sama tidak berbeda nyata pada taraf $5 \%\left(\mathrm{BNT}_{0.05}\right)$.

Tabel 4 menunjukkan bahwa intensitas serangan penyakit busuk batang umur 15 dan 30 HSI tidak berbeda nyata pada kedua varietas yang diuji. Namun pada umur 45 dan 60 HST intensitas serangan penyakit busuk batang di lahan gambut tertinggi dijumpai pada perlakuan varietas Takar $2\left(\mathrm{~V}_{2}\right)$, yang berbeda nyata dengan varietas Bison $\left(\mathrm{V}_{1}\right)$. Sedangkan intensitas serangan terendah dijumpai pada perlakuan varietas Bison $\left(\mathrm{V}_{1}\right)$, rendahnya intensitas serangan pada varietas bison hal ini di duga karena varietas Bison mempunyai tingkat daya ketahanan genetiknya yang baik. Menurut Brim (1992) dalam Agustian (1994), komponen pertumbuhan setiap varietas disamping dipengaruhi oleh faktor interaksi lingkungan juga dapat dipengaruhi oleh sifat genetiknya. Selain itu tinggi rendahnya pertumbuhan tanaman dipengaruhi oleh dua faktor yaitu faktor internal dan factor eksternal. Faktor internal merupakan faktor yang dipengaruhi oleh sifat genetik atau sifat turunan seperti umur tanaman, morfologi tanaman, daya hasil, kapasitas menyimpan cadangan makanan, ketahanan terhadap penyakit dan lain-lain. Faktor eksternal merupakan faktor lingkungan, seperti iklim, tanah dan faktor biotik (Gardner et al. 1991).

Penyebaran dan tingkat serangan penyakit tergantung pada tingkat ketahanan varietas dan kondisi lingkungan seperti suhu, kelembaban udara, tanaman inang serta media penularan (Pensuk et al. 2003). Adapun peningkatan intensitas serangan pada umur 60 HST (varietas bison) dan umur 45, 60 HST (varietas takar 2), hal ini diakibatkan karena kondisi $\mathrm{pH}$ tanah yang diberi perlakuan pengapuran maupun tanpa pengapuran masih mendukung perkembangan fungi $S$. rolfsii dan juga kondisi lingkungan seperti suhu yang kurang optimum.

Pada varietas bison, intensits serangan $S$. rolfsii umur 15,30 , dan 45 HST masing - masing sebesar 28.81; $10.41 ; 6.77$ penurunan intensitas serangan S. rolfsii pada tanaman kacang tanah terus mengalami penurunan hingga umur tanaman 45 HST. Pada umur tanaman 60 HST, intensitas serangan $S$. rolfsii mengalami peningkatan dari $6.77 \quad$ (45 HST) menjadi 8.00 (60 HST). Hal ini diduga disebabkan oleh faktor lingkungan (hujan) pada hari ke - 59 yang menyebabkan sclerotia $S$. rolfsii kembali berkecambah dan menyerang tanaman kacang tanah. Sesuai dengan pernyataan Kurnianti (2012), pembiakan fungi sclerotia dapat dipengaruhi oleh musim kemarau dan musim hujan. Faktor - faktor yang mempengaruhi sclerotia adalah jarak tanam musim dan keadaan lingkungan disekitarnya.

Pada varietas takar 2, intensitas serangan $S$. rolfsii umur 15 , 30, dan 45 HST masing - masing sebesar 34.16; 27.37; 28.81 penurunan intensitas serangan S.rolfsii pada tanaman kacang tanah terus mengalami penurunan hingga umur tanaman 45 HST. Pada umur tanaman 60 HST, intensitas serangan $S$. rolfsii mengalami peningkatan dari 28.81 (45 HST) menjadi 31.24 (60 HST). Hal ini 
diduga disebabkan oleh faktor lingkungan (hujan) pada hari ke - 42 yang menyebabkan sclerotia $S$. rolfsii kembali berkecambah dan menyerang tanaman kacang tanah. Sesuai dengan pernyataan Kurnianti (2012), pembiakan fungi sclerotia dapat dipengaruhi oleh musim kemarau dan musim hujan. Faktor - faktor yang mempengaruhi sclerotia adalah jarak tanam musim dan keadaan lingkungan di sekitarnya.

\section{Jumlah Sclerotia Terbentuk}

Rata-rata jumlah sclerotia terbentuk penyakit busuk batang pada berbagai varietas dilahan gambut disajikan pada Tabel 5.

Tabel 5. Rata-rata jumlah sclerotia terbentuk penyakit busuk batang pada berbagai varietas di lahan gambut

\begin{tabular}{cc}
\hline Perlakuan & Jumlah Sclerotia \\
\hline Bison $\left(\mathrm{V}_{1}\right)$ & 2,56 \\
Takar 2 $\left(\mathrm{V}_{2}\right)$ & 9,65 \\
\hline
\end{tabular}

Tabel 5 menunjukkan bahwa jumlah sklerotia terbentuk terbanyak dijumpai pada perlakuan varietas Takar 2 $\left(\mathrm{V}_{2}\right)$. Hal ini menunjukkan bahwa varietas Takar $2\left(\mathrm{~V}_{2}\right)$ sangat rentan terserang Sclerotium rolfsii. Sklerotia berbentuk butiran sangat kecil (diameter $0.5-1 \mathrm{~mm}$ ). Berwarna putih saat baru tumbuh dan berubah menjadi kecoklatan setelah tua, biasanya mudah ditemukan dipermukaan tanah sekitar lubang tanam dan pangkal batang (Mehan et al. 1995 dalam Agrios 2005).

Sclerotium rolfsii merupakan parasit tular tanah yang cukup berbahaya bagi tanaman karena dapat bertahan hidup sangat lama dalam bentuk sclerotia. Bagian dinding sclerotia mengandung gula, kitin, laminarin, asam lemak, dan B,1-3 glukosida. Tipe perkecambahan sclerotia berbentuk dispersif, dimana hifa akan keluar dari semua sudut sclerotia dan selanjutnya akan membentuk lapisan miselium dengan benang-benang halus bercabang berbentuk seperti kapas dan berwarna putih (Magenda 2011). S.rolfsii mampu menginfeksi tanaman bila jumlah miselium yang tumbuh cukup banyak. Miselium ini akan menyebar diseluruh permukaan tanah dan pangkal batang tanaman, sehingga dapat menyebabkan penyakit bagi tanaman tersebut dan secara perlahan dapat menyebabkan kematian. S.rolfsii akan mengabsorbsi makanan dari tanaman inang, sehingga hal tersebut dapat melemahkan tanaman inang (Gafur 2003).

\section{Masa Inkubasi \\ Masa inkubasi penyakit busuk batang pada berbagai varietas dilahan gambut disajikan pada Tabel 6 .}

Tabel 6. Masa inkubasi penyakit busuk batang terhadap tanaman kacang tanah pada berbagai varietas

\begin{tabular}{cc}
\hline Varietas & Masa Inkubasi (hari) \\
\hline Bison (V1) & 7 \\
Takar 2 (V2) & 7 \\
\hline
\end{tabular}

Tabel 6 menunjukkan bahwa masa inkubasi penyakit busuk batang tanaman kacang tanah relatif sama pada kedua varietas yang diuji, rata-rata dimulai pada 7 hari setelah inokulum. Hal ini menunjukkan Sclerotium rolfsii mampu menginfeksi tanaman. Masa inkubasi merupakan interval waktu dari inokulasi 
hingga muncul gejala. Menurut Agrios (1997), masa inkubasi pada tanaman kacang tanah pada perlakuan konsentrasi inokulum $80 \mathrm{gr} / 5 \mathrm{~kg}$ tanah yaitu 10 hari setelah tanam.

Fungi S. rolfsii tetap dapat menginfeksi akar tanaman kacang tanah karena $S$. rolfsii mampu mengeluarkan eksudat berupa ikatan ion, protein, karbohidrat, enzim endopoligalakturonase, dan asam oksalat. Asam oksalat ini bersifat racun terhadap tanaman (fitotoksik), sehingga menyebabkan terganggunya metabolisme pada tanaman inang (Sumartini 2012). Menurut Gafur (2003), Fungi $S$. rolfsii diketahui mampu menghasilkan enzim kutinase ketika menginfeksi tanaman inang. Enzim kutinase merupakan salah satu enzim yang penting bagi perkembangan fungi, terutama untuk menghancurkan dan menembus kutikula dinding sel tanaman agar fungi dapat mempenetrasi jaringan tersebut. Enzim endopoligalakturonase yang dihasilkan oleh fungi juga berperan dalam penghancuran sel tanaman.

\section{Pengaruh Dosis Pengapuran}

Hasil uji $F$ pada analisis ragam (Lampiran bernomor genap 3 sampai 26) menunjukkan bahwa dosis pengapuran berpengaruh tidak nyata terhadap persentase tanaman terserang umur 7,14 , 21, 28, 35, 42 dan 49 HSI, Intensitas serangan 15, 30, 45 dan 60 HST, masa inkubasi dan jumlah sklerotia terbentuk.

\section{Persentase Tanaman Terserang (\%) \\ Rata-rata persentase tanaman terserang penyakit busuk batang pada berbagai dosis pengapuran umur 7, 14, 21, 28, 35, 42 dan 49 HSI di lahan gambut setelah uji $\mathrm{BNT}_{0.05}$ disajikan pada Tabel 7.}

Tabel 7. Rata-rata persentase tanaman terserang penyakit busuk batang pada berbagai dosis pengapuran umur 7, 14, 21, 28, 35, 42 dan 49 HSI di lahan gambut

\begin{tabular}{cccc}
\hline \multirow{2}{*}{$\begin{array}{c}\text { UmurTanaman } \\
(\mathrm{HSI})\end{array}$} & \multicolumn{3}{c}{ Persentase Tanaman terserang $(\%)$} \\
\cline { 2 - 4 } & Tanpa Pengapuran $\left(\mathrm{K}_{0}\right)$ & $\begin{array}{c}10 \text { ton/ha } \\
\left(\mathrm{K}_{1}\right)\end{array}$ & $\begin{array}{c}20 \text { ton/ha } \\
\left(\mathrm{K}_{2}\right)\end{array}$ \\
\hline 7 & 51.29 & 54.16 & 47.41 \\
14 & 56.21 & 57.84 & 36.39 \\
21 & 18.73 & 19.08 & 15.46 \\
28 & 13.83 & 20.37 & 20.80 \\
35 & 12.54 & 19.17 & 20.89 \\
42 & 16.58 & 21.58 & 23.22 \\
49 & 16.58 & 21.58 & 25.80 \\
\hline
\end{tabular}

Tabel 7 menunjukkan bahwa persentase tanaman terserang penyakit busuk batang pada $7,14,21,28,35,42$ dan 49 HSI tidak berbeda nyata pada semua perlakuan berbagai dosis pengapuran. Hal ini diduga karena setelah pemberian kapur, fungi $S$. rolfsii masih mampu berkembang dan menyerang tanaman kacang tanah. Hasil pengukuran $\mathrm{pH}$ awal 3.90 dan pengukuran $\mathrm{pH} 14$ hari setelah pengapuran 4.11 (K0), 5.65 (K1), 6.25 (K2). Sesuai dengan pendapat Ferreira dan Boley (2006) yang menyatakan bahwa fungi $S$. rolfsii mampu tumbuh di tanah masam hingga netral, dengan $\mathrm{pH} 3.0$ hingga $\mathrm{pH}$ 7.0. Sclerotium rolfsiiakan terhambat pertumbuhannya pada $\mathrm{pH}$ lebih dari 7.0. Wahyanto dan Subiksa (2011) tanah gambut juga merupakan lahan hasil akumulasi timbunan bahan organik yang berasal dari pelapukan vegetasi yang tumbuh di sekitarnya dan terbentuk secara alami dalam jangka waktu yang lama, sehingga fungi akan dengan mudah berkembang. Jumlah inokulum Sclerotium rolfsii yang sama jumlahnya perannya 
sama dalam menentukan terjadinya penyakit. Adapun peningkatan persentase serangan pada umur 42 HSI (varietas bison), dan 42 HSI (varietas takar 2), hal ini diakibatkan karena kondisi $\mathrm{pH}$ tanah gambut yang tanpa pengapuran maupun diberi pengapuran masih mendukung untuk pertumbuhan fungi $S$. rolfsii, sehingga fungi $S$. rolfsii akan lebih mudah berkembang.

\section{Intensitas Serangan}

Rata-rata intensitas serangan penyakit busuk batang pada berbagai dosis pengapuran umur 15, 30, 45 dan 60 HST dilahan gambut disajikan pada Tabel 8 .

Tabel 8. Rata-rata intensitas serangan penyakit busuk batang pada berbagai dosis pengapuran umur 15, 30, 45 dan 60 HST di lahan gambut

\begin{tabular}{cccc}
\hline \multirow{2}{*}{$\begin{array}{c}\text { Umur Tanaman } \\
(\mathrm{HST})\end{array}$} & \multicolumn{3}{c}{ Intensitas Serangan } \\
\cline { 2 - 4 } & Tanpa Pengapuran $\left(\mathrm{K}_{0}\right)$ & $\begin{array}{c}10 \text { ton/ha } \\
\left(\mathrm{K}_{1}\right)\end{array}$ & $\begin{array}{c}20 \text { ton/ha } \\
\left(\mathrm{K}_{2}\right)\end{array}$ \\
\hline 15 & 33.95 & 36.18 & 24.33 \\
30 & 21.27 & 16.16 & 19.24 \\
45 & 13.30 & 16.60 & 18.73 \\
60 & 15.62 & 20.34 & 28.67 \\
\hline
\end{tabular}

Tabel 8 menunjukkan bahwa intensitas serangan penyakit busuk batang pada berbagai dosis pengapuran umur 15 , 30, 45 dan 60 HST di lahan gambut tidak berbeda nyata pada semua perlakuan berbagai dosis pengapuran. Hal ini di disebabkan perlakuan pengapuran tidak menghambat perkembangan fungi. Menurut Hemon dan Windarningsih (1991) intensitas serangan dari masingmasing varietas kacang tanah yang telah terserang jamur pada deskripsi gejala serangan pada hari tertentu akan mempengaruhi jumlah sclerotium pada tanaman. Pada tanah gambut Sclerotium rolfsii akan dengan mudah berkembang, hal ini diakibatkan karena kondisi tanah yang terlalu masam sehingga jamur dengan mudah menyerang tanaman kacang tanah yang menyebabkan keparahan pada tanaman yang telah terserang seperti busuk batang, layu dan rebah kecambah (Timper et al. 2001).

Menurut Pensuk (2003)
menyatakan, penyebaran dan tingkat serangan penyakit tergantung pada kondisi lingkungan seperti suhu, kelembaban udara, tanaman inang serta media penularan. Hal ini sesuai dengan pernyataan Sinclair dan Backman (1989) bahwa jumlah inokulum fungi Sclerotium rolfsii sangat besar peranannya dalam menentukan terjadinya serangan penyakit. Adapun peningkatan intensitas serangan pada umur 60 HST (varietas bison), dan 45 HST (varietas takar 2), hal ini diakibatkan karena kondisi $\mathrm{pH}$ tanah yang diberi perlakuan pengapuran maupun tanpa pengapuran masih mendukung perkembangan fungi $S$. rolfsii dan juga kondisi lingkungan seperti suhu yang kurang optimum.

\section{Jumlah Sklerotia Terbentuk}

Rata-rata jumlah sklerotia terbentuk penyakit busuk batang pada berbagai dosis pengapuran dilahan gambut disajikan pada Tabel 9. 
Tabel 9. Rata-rata jumlah sklerotia terbentuk penyakit busuk batang pada berbagai dosis pengapuran di lahan gambut

\begin{tabular}{cc}
\hline Perlakuan & Jumlah Sclerotia Terbentuk \\
\hline Tanpa Pengapuran $\left(\mathrm{K}_{0}\right)$ & 8.78 \\
10 ton/ha $\left(\mathrm{K}_{1}\right)$ & 6.26 \\
20 ton/ha) $\left(\mathrm{K}_{2}\right)$ & 3.28 \\
\hline
\end{tabular}

Tabel 9 menunjukkan bahwa jumlah sclerotia terbentuk pada berbagai dosis Tanpa Pengapuran $\left(\mathrm{K}_{0}\right), 10$ ton/ha $\left(\mathrm{K}_{1}\right), 20$ ton/ha $\left(\mathrm{K}_{2}\right)$ di lahan gambut tidak berbeda nyata pada semua perlakuan berbagai dosis pengapuran. Hal ini terjadi karena sclerotia akan dengan mudah berkembang ketika sebagian dari penyakit menjadi hifa/miselium pada kondisi suhu optimum sehingga dapat menginfensi tanaman sampel. Menurut hasil penelitian yang telah dilakukan selama tiga bulan dengan kisaran suhu per bulan adalah Mei (29-31 $\left.{ }^{0} \mathrm{C}\right)$, Juni $\left(27-30^{\circ} \mathrm{C}\right)$, Juli $\left(29-31^{\circ} \mathrm{C}\right)$, dan Agustus $\left(27-30^{\circ} \mathrm{C}\right)$.
Suhu optimum bagi perkembangan Sclerotium rolfsii berkisar $25-32^{\circ} \mathrm{C}$, dengan suhu minimum $7^{\circ} \mathrm{C}$ dan suhu maksimum $\quad 35^{\circ} \mathrm{C}$. Perkecambahan sklerotium yang optimum terjadi pada kisaran suhu $21-30^{\circ} \mathrm{C}$. Pada suhu $0^{\circ} \mathrm{C}$, hifa akan mati dan tidak dapat membentuk sklerotium, dan pada suhu $10^{\circ} \mathrm{C}$ sklerotium akan mati (Sumartini 2012).

\section{Masa Inkubasi}

Masa inkubasi penyakit busuk batang pada berbagai dosis pengapuran dilahan gambut disajikan pada Tabel 10.

Tabel 10. Masa inkubasi penyakit busuk batang terhadap tanaman kacang tanah pada berbagai dosis pengapuran di lahan gambut

\begin{tabular}{cc}
\hline Pengapuran (ton/ha) & Masa Inkubasi (hari) \\
\hline Tanpa Pengapuran $\left(\mathrm{K}_{0}\right)$ & 7 \\
10 ton/ha & 7 \\
20 ton/ha & 7 \\
\hline
\end{tabular}

Tabel 10 menunjukkan bahwa masa inkubasi penyakit busuk batang tanaman kacang tanah relatif sama pada berbagai dosis pengapuran yang diuji, rata-rata dimulai pada 7 hari setelah inokulasi. Masa akhir inkubasi bervariasi karena dipengaruhi oleh faktor lingkungan yang mempengaruhi perkembangan jamur. Tanah gambut merupakana tanah dengan $\mathrm{pH}$ yang rendah dan sangat mendukung untuk perkembengan jamur. Ferreira dan Boley (2006) yang menyatakan bahwa jamur mampu tumbuh di tanah masam hingga netral, dengan $\mathrm{pH} 3.0$ hingga $\mathrm{pH}$ 7.0. Sclerotium rolfsii akan terhambat pertumbuhannya pada $\mathrm{pH}$ lebih dari 7.0 pada tanaman kacang-kacangan.

\section{Interaksi}

Hasil uji $F$ pada analisis ragam (genap 3 sampai 26) menunjukkan bahwa tidak terdapat interaksi antara dosis pengapuran dengan varietas terhadap semua peubah yang diamati. Hal ini menunjukkan bahwa perbedaan tingkat serangan Sclerotium rolfsii pada tanaman kacang tanah akibat berbedanya dosis pengapuran tidak tergantung pada varietas, begitu pula sebaliknya.

\section{KESIMPULAN}

1. Varietas bison lebih tahan terhadap serangan penyakit busuk batang $S$. rolfsii dibandingkan dengan varietas takar 2 pada lahan gambut. 
2. Dosis pengapuran berpengaruh tidak nyata pada semua parameter pengamatan terhadap serangan penyakit busuk batang $S$. Rolfsii pada lahan gambut.

3. Tidak terdapat interaksi antara varietas dan dosis pengapuran terhadap serangan Sclerotium rolfsii pada tanaman kacang tanah di lahan gambut.

\section{DAFTAR PUSTAKA}

Achmad, Hadi S, Harran S, Sa'id EG, Satiawiharja B, Kardin MK. 2012. Mekanisme serangan pathogen lodoh pada semai pinus (Pinus merkusii). Journal of Tropical Silviculture Science and Technology. 03(1):57-64 Adisarwanto T. 2000. Meningkatkan Produksi Kacang Tanah di Lahan Sawah dan Lahan Kering. Jakarta (ID): Penumbra Swadaya

Agrios GN. 1997. Plant Pathology. New York (US): Academic Press Terjemahan. Ilmu Penyakit Tumbuhan. Yogyakarta (ID): Gadjah University Press

Agustian. 1994. Pengaruh pemberian kombinasi fosfat dengan kalium terhadap pertumbuhan dalam hasil dua varietas kacang tanah (Arachis hypogea L.) [skripsi]. Banda Aceh (ID): Universitas Syiah Kuala

Direktorat Budidaya Aneka Kacang dan Umbi. 2008-2012. Pedoman Teknis Pengolahan Kacang Tanah, Kacang Hijau, dan aneka Kacang Tahun 2012. Direktorat Jendral Tanaman Pangan (Ditjentan). Jakarta (ID) : Kementrian Pertanian

Fichtner. 2010. Sclerotium rolfsii kudai of the fungal world [internet]. [diunduh 2017 Mei 23]. Tersedia pada: http//www. cals. Edu/course/pp 728/Sclerotium rolfsii/ S.rolfsii

Gardner FP, Pearce RB, Mitchell RL.1991. Physiologi of Crop Plants. Diterjemahkan oleh H. Susilo. Jakarta (ID): Universitas Indonesia Press
Gafur, Abdul. 2003. Aspek fisiologis dan biokimia infeksi jamur pathogen tumbuhan. Jurnal Hama dan Penyakit Tumbuhan Tropika. 3 (1)

Hemon F, M Wandarningsih. 1991. Uji ketahanan beberapa varietas kacang tanah terhadap penyakit becak daun cercospora personata (Berg dan Curt) Dalam Prosiding Kongres Nasional XI dan Seminar III PFI Maros, Ujung Pandang (ID0. 40-50 h

Kurnianti N. 2012. Budidaya Cabai. [Internet]. [Diunduh 2017 Mei 15] Tersedia pada: Http://www. tanijogonegoro. Com/2012/10/carapraktis-bididaya-cabai. Html

Magenda S, Kandao F, Umboh S. 2011. Karakteristik isolat jamur Sclerotium rolfsii dari tanaman kacang tanah (Arachis hypogaea Linn). J Bioslogos. 1: 17-23

Marzuki. 2007. Bertanam Kacang Tanah. Jakarta (ID) : Penerbit Swadaya

Pensuk VA. Patanothai, S Jogloy, S Wongkaew, C Akkasaeng, N Vorasoot. 2003. Reaction of peanut cultivars to late and rust. Songklanakarin J. Sci.Tech. 25 (3): 289-295

Semangun. 2004. Penyakit-Penyakit Tanaman Pangan di Indonesia. Yogyakarta (ID) : Gajah Mada University.

Sinclair JB, BA Backman. 1989. Compendium of Soybean Diseases. New York (US): The American Phytopathological Society. United States of Amerika 3rd Ed.

Singh RRP. 2006. Breeding for Resistance to Biotic Stresses. in AR Lamkey dan M. Lee (Eds.). Plant Breeding. Iowa (USA): $\quad$ Lackwell Publikation. 310-322 p

Suprapto. 2004. Komunikasi Penyuluhan dalam Teori dan Praktek. Yogyakarta (ID): Penerbit Arti Bumi Intaran

Sumartini. 2012. Penyakit Tukar Tanah (Sclerotium rolfsii dan Rhizoctonia solani) pada Tanaman Kacang- 
kacangan dan Umbi-umbian Serta Cara Pengendaliannya. Bogor (ID): Balai Penelitian Kacang-kacangan dan Umbi-umbian

Timper. 2001. Influence of cropping system on stem rot (Sclerotium rolfsii), Meloydogyne arenaria, and the nematode antagonist Pasteuria penetrans in peanut. Plant Disease. 85:767-772

Tim Bina Karya Tani Kacang Tanah. 2009. Pedoman Bertanam Kacang Tanah. Jakarta (ID): Yrama Widya. Cetakan 1

Wahyanto, Subiksa IGM. 2011. Genesis Lahan Gambut Indonesia. Bogor (ID) : Balai Penelitian Tanah. 3-14 